Paper accepted for publication in Academy of Management Perspectives. Please cite as:

De Massis, A., Frattini, F., Kotlar, J., Messeni-Petruzzelli, A., Wright, M. 2016. Innovation through tradition: Lessons from innovative family businesses and directions for future research. Academy of Management Perspectives, in press.

\title{
INNOVATION THROUGH TRADITION: LESSONS FROM INNOVATIVE FAMILY BUSINESSES AND DIRECTIONS FOR FUTURE RESEARCH
}

\author{
Alfredo De Massis \\ Lancaster University \\ a.demassis@lancaster.ac.uk \\ Federico Frattini \\ Politecnico di Milano \\ federico.frattini@polimi.it
}

Josip Kotlar

Lancaster University

j.kotlar@lancaster.ac.uk

Antonio Messeni Petruzzelli

Politecnico di Bari

antonio.messenipetruzzelli@poliba.it

Mike Wright (corresponding author)

Imperial College

mike.wright@imperial.ac.uk

\section{Acknowledgements}

We are indebted to professor Timothy Devinney, the AMP Editor, and the anonymous reviewers for their thoughtful and valuable feedback. An earlier version of this paper won the Best Practitioner Focused Paper Award at the 2014 Family Enterprise Research Conference (FERC). We would like to thank the Institute for Family Business (IFB) and the Knowledge Exchange Team of ESI at Lancaster University Management School for stimulating us to better understand the challenges and dilemmas of the family business sector at the interface of tradition and innovation. We also would like to express our gratitude to Aboca, Apreamare, Beretta, Lavazza, Sangalli and Vibram: their insights were crucial for developing the research underlying this article. Finally, we owe many thanks to the numerous researchers and practitioners who provided comments and feedback on our original ideas at conferences (FERC 2014, the Family Enterprise Day of the 2015 IFERA conference "Innovation and Tradition in Family Business", the 12th European Families in Business Conference organized by Campden FB and the R\&D Management Conference 2015) and workshops organized by the Family Owned Business Institute (FOBI, Grand Valley State University), Universidad del Desarrollo and the Family Business Network (FBN). 
INNOVATION THROUGH TRADITION: LESSONS FROM INNOVATIVE FAMILY

BUSINESSES AND DIRECTIONS FOR FUTURE RESEARCH

\begin{abstract}
In steering towards the future, innovation managers are commonly advised to dismiss the old and make way for the new. However, such "recency bias" may significantly limit a firm's innovation potential and prevent it from realizing the benefits of past knowledge. We argue that the temporal dimension of innovation deserves more research attention. Combining prior research on innovation, dynamic capabilities and family business, we conceptualize a new product innovation strategy called innovation through tradition (ITT) and identify its underlying capabilities of interiorizing and reinterpreting past knowledge. The illustrative cases of six longlasting family businesses (Aboca, Apreamare, Beretta, Lavazza, Sangalli and Vibram) are analyzed and discussed, hence exemplifying how firms that build long-lasting and intimate links with their traditions can be extremely innovative while remaining firmly anchored to the past. These examples help visualize theoretical concepts and recognize the potential advantages of past knowledge in terms of value creation and capture. We develop an agenda for future research aimed at improving our understanding of the temporal search processes involved in the ITT strategy, within and outside the family business field, and thus contribute to innovation and organizational learning studies. Managers of non-family firms can learn from the family businesses that successfully use ITT to create and nurture a competitive advantage and emulate them by leveraging rather than discarding tradition.
\end{abstract}

Keywords: family business, tradition, innovation, dynamic capabilities, heritage, temporal search 
Product innovation is a vital source of competitive advantage (e.g., Banbury and Mitchell, 1995; Calantone, Chan, \& Cui, 2006). According to conventional thinking in innovation, relying on knowledge from the past can cause path-dependence, inflexibility and conservatism, thus reducing a firm's capability to successfully innovate (Leonard-Barton, 1992) and meet current environmental needs and expectations (Sorensen \& Stuart, 2000). Managers are therefore commonly advised to create a corporate sense of urgency and obtain a mandate to dismiss the past and open the doors to the future (Adner \& Snow, 2010). Scholars have only recently started to recognize the potential benefits of searching in the past to develop innovative products (e.g., Katila, 2002; Messeni Petruzzelli \& Savino, 2014; Nerkar, 2003). Customers increasingly look for responses to their needs to repossess the past and look back for guidance from less chaotic and unstable times (Brown, 2001). Therefore integrating knowledge from the past in new products can elicit positive feelings and legitimize innovative functionalities (Wang \& Wallendorf, 2006; Ryder, 2014). Thus, downplaying the past in innovation is more a cultural choice than an imperative or strategic need. In other words, it is the result of a "recency bias" that may inadvertently hinder a firm's innovation performance (e.g., Katila, 2002; Capaldo, Lavie, \& Messeni Petruzzelli, 2014). Indeed, knowledge pertaining to the past is increasingly recognized as a powerful and unique source of innovation advantage (Messeni Petruzzelli \& Albino, 2012). As such, the conventional view of the past in innovation research may prove inadequate or even counterproductive and the scant attention to the temporal dimension of innovation search processes - that is, how firms gain access to and use knowledge that has been developed in the past to innovate (Nerkar, 2003) - emerges as a significant gap in innovation research (Savino, Messeni Petruzzelli, \& Albino, 2015). 
Despite increasing awareness among scholars and practitioners that past knowledge has the potential to sustain and enhance a firm's innovation performance (e.g., Messeni Petruzzelli \& Albino, 2012), existing research offers little help to understand why the past can be valuable and how managers can leverage it to innovate. How can we develop a thorough understanding of the value of the past in innovation? How can future research be shaped to further our understanding of this possible phenomenon? We provide a first attempt to address these questions by developing the concept of innovation through tradition (ITT), a product innovation strategy that firms can apply to leverage temporally distant knowledge and develop product innovations. By integrating insights from different research streams, namely, product innovation and knowledge search, family business and dynamic capabilities, we advance a model of ITT that maps the process through which firms can gain access to and use past knowledge, and highlights the capabilities firms need to develop in order to interiorize and reinterpret past knowledge to innovate. Illustrative vignettes from six long-lasting and innovative family businesses (Aboca, Apreamare, Beretta, Lavazza, Sangalli and Vibram) are used to exemplify how the past can sustain product innovation and how ITT is applied in practice (Siggelkow, 2007).

Family businesses appear a particularly well suited context to appreciate how the past can be leveraged in innovation. Indeed, the extraordinary longevity and long-term orientation of some family businesses (Miller \& Le Breton-Miller, 2005) can result in a special capability to create links between their past, present and future (e.g., Zellweger, Nason, \& Nordqvist, 2012), enabling them to search and recombine temporally distant knowledge to develop new products. This capability allows many family businesses to innovate by exploiting knowledge pertaining to the firms' tradition and to that of their territory. However, non-family businesses can learn to leverage knowledge from the past for successful product innovation as well, pointing to a 
broader applicability of ITT outside the family businesses context. In this vein, we advance ideas for extending the concept of ITT beyond the context of family business and outline an agenda of promising directions for future research.

\section{THEORETICAL BACKGROUND}

Product innovation has long been a source of competitive advantage, allowing firms to enlarge existing markets and create new ones (e.g., Banbury and Mitchell, 1995; Calantone et al., 2006). Product innovation involves a knowledge search and recombination process, whereby firms search for knowledge components across multiple domains in an attempt to identify novel combinations (Henderson \& Clark, 1990). Our focus is on product innovation rather than on service, process or business model innovation as the benefits resulting from searching knowledge across multiple domains is perhaps most tangible in new products (Wang and Wallendorf, 2006). This conceptualization of innovation as a knowledge search and recombination process (e.g., Ahuja, Lampert, \& Tandon, 2008) is found in both high- and low-technology sectors (e.g., Khaire \& Wadwani, 2010).

\section{Is Tradition a Resource or a Liability?}

Research examining search processes in innovation focuses on two main dimensions of search. The first refers to the extent to which a firm uses a well-known pool of knowledge. This dimension is referred to as search depth and captures the extent to which firms search for knowledge within their existing knowledge bases (e.g., Miner, Bassof, \& Moorman, 2001; Stuart \& Podolny, 1996). Scholars have examined the costs and benefits of searching for knowledge in domains falling within the organization's existing competence bases (Katila \& Ahuja, 2002). These studies emphasize the importance of achieving a balance between exploration of novelty 
and exploitation of existing knowledge, which can be achieved through mechanisms such as ambidexterity or punctuated equilibrium (for a review, see Gupta, Smith, \& Shalley, 2006).

Search breadth is the second dimension of innovation search, capturing how widely a firm searches for new knowledge across multiple knowledge domains (Katila \& Ahuja, 2002). Searching across different geographic and technological contexts enables new product development (e.g., Rosenkopf \& Almeida 2003). However, over-searching across multiple domains incurs higher costs than searching extensively within a narrower set of knowledge domains (e.g., Laursen \& Salter, 2006), hence hindering innovation performance.

By focusing on these two dimensions, innovation scholars have overlooked the question of how firms search for innovation across time, hence devoting only scant attention to the dynamics characterizing the temporal search process, defined as the process through which firms search for knowledge that has been developed in the past (Nerkar, 2003). The paucity of such research mirrors the conventional assumption that successful innovation requires searching and recombining the most recent knowledge (e.g., Argote, 1999). Accordingly, the past is traditionally conceived as a source of resistance that leads to inertia, excessive path-dependency, the liability of senescence (Barron, West, \& Hannan, 1994) and core rigidity (Leonard-Barton, 1992). This is because old knowledge tends to become obsolete and does not meet current environmental needs and expectations (Sorensen \& Stuart, 2000), thus reducing the value and usefulness of the new products that embed such knowledge.

This adverse view of the past in innovation may generate a "recency bias" that leads firms to give excessive weight to the most recent knowledge and overlook the potential benefits of old knowledge (e.g., Katila, 2002; Capaldo et al., 2014). Accordingly, we call for a reconsideration of the conventional view of the past in innovation research and the 
recommendation for innovation managers to dismiss the old to make way for the new, which is based on the assumption that the value of knowledge decreases over time. Therefore, in an attempt to provide a deeper understanding of the temporal dimension of search process, in the following sections we discuss the benefits of searching over time for innovation, illustrate the competitive implications of this search process, and discuss why some firms are particularly well equipped to leverage the past to innovate.

\section{Temporal Search and Tradition}

Temporal search represents a third dimension along which the search process in innovation can take place, orthogonal to the search depth and breadth dimensions discussed above (Katila, 2002). In particular, it identifies the process through which firms "search for and access knowledge created at different points in the past in order to create new products" (Katila, 2002: 995). There are several potential benefits from using temporally distant knowledge including increased reliability, decreased risk of retaliation, and uniqueness (Katila, 2002). This view is supported by evidence highlighting the innovation benefits of searching across time (Messeni Petruzzelli, Rotolo, \& Albino, 2012), including reducing the risk from incorrect applications of new knowledge and increasing the reliability (Heeley \& Jacobsen, 2008) and legitimacy (Hargadon \& Douglas, 2001) of innovations. These benefits become especially important when consumers take refuge in the past for guidance in increasingly chaotic and culturally unstable times (Brown, 2001). Hence, relying upon past knowledge to innovate can be especially effective in specific industries, such as health, food, beverage and luxury, where customers exhibit an enduring need that may be satisfied by managing the tension between preservation and adaptation, thus enhancing the legitimacy of the innovative solutions and the likelihood of gaining acceptance within the market (Hargadon \& Douglas, 2001). 
The temporal search process is closely intertwined with the concept of tradition, which refers to the stock of knowledge, competencies, materials, manufacturing processes, signs, values and beliefs pertaining to the past (Messeni Petruzzelli \& Albino, 2012). Tradition involves accumulation of know-how, symbolic and cultural content, and micro-institutions of practice handed down across generations and contributing to shaping the identity of individuals, organizations, and territories (Hibbert \& Huxham, 2010). Following the resource-based view of the firm (Wernerfelt, 1984; Barney, 1991), tradition can be conceived as a distinctive and unique resource. Indeed, the sticky and embedded nature of tradition makes its imitation more difficult, thus contributing to its distinctiveness and rarity. Accordingly, firms capable of developing an appropriate set of dynamic capabilities that allow them to leverage a specific tradition may be able to create and capture value from innovation and thus create and nurture competitive advantage.

\section{Dynamic Capabilities, Creating Value and Capturing Value with Innovation}

Capabilities represent a key source of firm competitive advantage (e.g., Barney, 1991; Winter, 2003). Differences in these capabilities may contribute to explaining heterogeneity in performance and competitiveness. A particular subset of firm's capabilities, known as dynamic capabilities (Helfat \& Peteraf, 2003), are important in enabling a firm to effectively respond to changes in the competitive environment, by combining and reconfiguring its bundle of resources over time. Accordingly, dynamic capabilities play a crucial role in allowing a firm to delve into a specific tradition to create value through new products (Giddens, 1990) and turn these new products into a superior competitive advantage by capturing value from them (Teece, 1986).

In terms of value creation, the importance of the past in influencing consumer behavior is noted not only in business and economics, but also in sociology and psychology. Consumers 
often indulge in nostalgia (Brown, Kozinets, \& Sherry, 2003) when they are unhappy with the present or frightened of the future. Indeed, the sense of identity of individuals is strongly based on the past and nostalgia reaffirms social identities that have been impaired by the turmoil brought about by uncertainty and instability (Inglehart \& Baker, 2000; de Janasz, Sullivan, \& Whiting, 2003). Thus, tradition enables firms to elicit strong and positive feelings, increasing the value of new products by embedding past knowledge, facilitating the legitimacy of innovative functionalities and meanings and the likelihood of obtaining market acceptance (Ryder, 2014). Furthermore, the past often helps individuals make sense of the present (Shils, 1981). Using resources drawn from a specific tradition in the innovation process allows positioning new products in a well-defined temporal and geographic space, evoking memories and experiences to respond to the need for product distinctiveness and to bring to the customer's mind less chaotic and culturally unstable times (Messeni Petruzzelli \& Savino, 2014).

In terms of value capture, relying on the past means developing product innovations anchored in a specific tradition, which may pertain to the firm and/or its territory (Hibbert \& Huxham, 2010). In turn, tradition is a highly idiosyncratic and unique resource that cannot be easily replicated by others (Kanter, 1995). This allows firms to develop innovations characterized by a high level of uniqueness. Uniqueness is a tremendous source of bargaining power and key to appropriating innovation rents (Teece, 2006; Di Minin \& Faems, 2013), thus requiring relatively less access to complementary assets to capture value from innovation. This explains why tradition may be a key resource for small or medium-sized firms, which are likely to be at a disadvantage compared with larger competitors in terms of bargaining for the development and acquisition of complementary assets such as manufacturing capacity, brand awareness or access to distribution channels (Arora et al., 2009). Furthermore, tradition may 
enable firms to innovate by building on more reliable knowledge and resources, extensively validated over time, and hence reduce development and utilization costs and increase profits from introducing new products (Heeley \& Jacobson, 2008).

\section{Tradition and Family Businesses}

Family businesses represent an organizational form particularly well suited to leverage tradition in product innovation. Prior family business research can help gain a deeper understanding of how firms can innovate through tradition. Definitions of family businesses vary greatly (Chua, Chrisman \& Sharma, 1999; De Massis et al., 2012) and researchers recognize that family businesses are highly heterogeneous (Wright et al., 2014; Chua et al., 2012; De Massis, Kotlar et al., 2014). As suggested by Chua et al. (1999: 25), our focus is on family businesses "governed and/or managed with the intention to shape and pursue the vision of the business held by a dominant coalition controlled by members of the same family or a small number of families in a manner that is potentially sustainable across generations". This definition emphasizes that in some family businesses, the values and beliefs of the founding family are handed down across generations for decades, sometimes centuries, such that organizational culture and identity closely reflect the way the firm has operated in the past (Gagné et al., 2014; Le Breton-Miller \& Miller, 2008; Tapies \& Ward, 2008). In these firms, family history pervades business practices, producing and reinforcing shared values, norms and beliefs over time, and creating a close link between the present and the past (Zellweger et al., 2012).

Due to their strong links with the past, family businesses are conventionally seen as conservative, path-dependent and ultimately less innovative than non-family counterparts (Gómez-Mejía et al., 2007). However, family businesses may display extremely diverse innovation behaviors and outcomes (Chrisman \& Patel, 2012; Kotlar et al., 2014; De Massis et 
al., 2016). Under certain circumstances, family businesses are even more innovative than their non-family counterparts (Patel \& Chrisman, 2014; De Massis, Di Minin \& Frattini, 2015) and better able to convert innovation input into output (Duran et al., 2015).

We argue that long-lasting family businesses can have an advantage in their privileged access to past knowledge and that the innovation success of these firms can be explained by their capabilities to leverage tradition to develop successful new products. Indeed, the long-lasting involvement in ownership and management characterizing some founding families, their socioemotional wealth, and the resulting strong links with the past, can represent valuable resources for innovation. The unique opportunities these family businesses have to create and maintain a link with the past can streamline temporal search processes and facilitate the identification of past knowledge, enabling the effective use of this knowledge leading to successful innovations. Some family businesses are endowed with unique capabilities allowing them to make the past available and understandable to employees involved in the innovation process, by putting in place organizational routines that ensure continuity across time and generations (Shils, 1981), hence preserving the original meaning and content of past knowledge (Hibbert \& Huxham, 2010). This in turn contributes to increasing the value of temporal search by overcoming the risk of misinterpretations, misunderstandings and misapplications (Argote, 1999), which may reduce the “inventor's ability to correctly recall, retrieve, and apply overly mature knowledge in an innovation" (Capaldo et al., 2014: 6). Therefore, long-lasting innovative family businesses can be particularly illuminating as to how the past can be valuable and to the distinctive capabilities needed to link the past, present and future in meaningful ways and purposefully search and recombine past knowledge to develop innovative products. 
INNOVATION THROUGH TRADITION: CONCEPTUALIZING A NEW PRODUCT INNOVATION STRATEGY

\section{Toward a Model of Innovation Through Tradition}

Competitive advantage requires a combination of good strategy, strong dynamic capabilities and difficult-to-imitate resources (Teece, 2014). Following this approach, understanding why and how ITT can lead to a competitive advantage requires identifying the idiosyncratic resources on which this strategy is built and the capabilities through which these resources are adapted, orchestrated and innovated over time (Teece, 2007). As discussed above, understanding how firms search and use past knowledge to innovate requires integrating a multitude of theoretical perspectives and diverse literature streams. The various theoretical concepts and relationships underlying ITT are systematized in Figure 1, which provides an integrative framework that highlights the main building blocks and outcomes of ITT. The framework aims at explaining how firms can develop new products by leveraging knowledge from the past.

\section{Insert Figure 1 about here}

We integrate different streams of research into this framework. The dynamic capability view (Helfat \& Peteraf, 2003) suggests that ITT is based on two key capabilities, i.e., interiorization and reinterpretation. Interiorization allows assimilating and sharing past knowledge stocks pertaining to the firm's tradition or the tradition of its territory across the entire organization, as reflected by the different forms of codified and tacit knowledge used to develop new products. Reinterpretation instead allows the combination of selected forms of past knowledge with up-to-date technologies to turn them into new products. Second, research on temporal search in innovation is used to identify the sources from which past knowledge, the 
idiosyncratic resource lying at the heart of ITT, can be searched and retrieved, i.e. the tradition of the firm itself or the tradition of the territory in which it is embedded (Messeni Petruzzelli \& Albino, 2012). Furthermore, knowledge management and organization studies suggest that, when firms interiorize past knowledge, this can take different forms, both codified and tacit, that feed the product innovation process (Cowan, David \& Foray, 2000). Finally, innovation research suggests that, by combining codified or tacit forms of past knowledge with new technologies, it is possible to elicit two different types of product innovation strategies, namely an innovation of the functionalities or an innovation of the meaning of the product (Veryzer, 1998). Figure 1 also points to several emerging themes that have been under-researched or addressed only in a fragmented way across different research streams. Most importantly, this model is used to identify gaps in our understanding of ITT and outline promising questions for future research. We therefore elaborate a future research agenda that provides scholars with promising directions to move forward the study of innovation through tradition and advance our understanding of how firms can leverage past knowledge to innovate.

\section{Illustrative Examples of Long-Lasting and Innovative Family Firms}

We complement the theoretical development with examples of six long-lasting and innovative family firms that, contrary to the conventional view, are extremely innovative by remaining anchored to tradition. We choose these six long-lasting and innovative family firms precisely because they are special in the sense that their capacity to innovate by maintaining a strong link with the past allows gaining of insights unavailable to most firms. Therefore, in accordance with previous studies (Siggelkow, 2007), these "extraordinary" cases seem to be a suitable choice to discuss and analyze the phenomenon under investigation. Our purpose here is not to report on an inductive study, but to use these examples as illustration. Therefore, we 
present the illustrative vignettes after the theory (Siggelkow, 2007). Using these illustrations, we clarify theoretical concepts and relationships, and show how the various conceptual issues included in the ITT framework are actually applied (Siggelkow, 2007: 22). Indeed, this approach allows for a close correspondence between theory and data (Glaser \& Strauss, 1967). Moreover, the combination of our theoretical arguments and these examples point to interesting avenues for future research that address the applicability of ITT also beyond family firms.

We draw on multiple and varied sources of information in developing the cases. Specifically, the collection of data lasted from 2009 to 2014, including company websites and other secondary sources of data, such as financial and business reports, presentations, press releases, magazine articles, and books. For some firms the secondary source data were corroborated with face-to-face interviews conducted with the CEOs and other family and nonfamily members responsible for product innovation, as well as with the direct observation of the new product development process. Data have been analyzed following an iterative process, moving from data to theory, and vice-versa (Strauss and Corbin, 1998), which enabled us to refine the ITT framework, better clarify its theoretical foundations, and illustrate how theoretical concepts work in practice. Finally, in order to ensure the integrity of our data, we triangulated the different and multiple sources, independently read the data and information, and discussed our interpretations in face-to-face meetings, hence solving potential misunderstandings and divergent views. Table 1 provides a brief description of the six family long-lasting and innovative family firms used in this article, which are briefly described below.

\section{Aboca: Historical Phytotherapy Meets Bio-Tech}

Aboca is an Italian family business leader in the production and commercialization of natural healthcare and beauty products, with a market share of $22 \%$ and a turnover of over 80 
million euro. The origin of the company dates back to 1978, when Valentino Mercati bought a farm in Tuscany to research the properties of ancient officinal herbs from the local territory and, in so doing, unveiled the potential of such knowledge for being combined with biotech technologies to create healthcare and beauty products. The firm is still fully controlled and managed by members of the Mercati family. By combining the properties of ancient and mostly forgotten herbs with up-to-date technologies, Aboca develops new products (such as GrinTuss, Melilax, Sollievo Bio 90, Adiprox and Bioanacid) that are enthusiastically received by the market because they are very effective without the side effects that characterize traditional drugs. Apreamare: Old Fishing Boats Turned into Luxury Yachts

Apreamare is a company located in the South of Italy that produces boats and yachts, with a turnover of around 20 million euros, 20 dealers throughout the world and over 185 employees worldwide. It was founded in 1849 when the shipbuilder Giovanni Aprea started hand building rowing and sailing boats for fishing in Sorrento, basing his craft on the shape and form of the traditional "gozzo sorrentino". After it was acquired by the Ferretti group in 2001, the company returned in the hands of the founding family in 2010. The local traditional art of craftsmanship has allowed handing down the vision, entrepreneurial spirit and manufacturing skills for more than a century, hence contributing to create a tight link between the firm and its territory, which results into a distinctive combination of tradition and modernity.

\section{Beretta: Craftsmanship Heritage Reinterpreted into Innovative Competition Shotguns}

Beretta is a 500-year-old, world-leading family business that reinterprets the founding family's traditional values for hunting and their long tradition of craftsmanship, recombining these with up-to-date technologies to enable radically new functionalities in their products. After 15 generations of continued family control, Beretta is the oldest gunsmith company in the world, 
with products ranging from handguns, rifles, and shotguns, as well as knives, accessories, and sporting apparel. The net total sales of the Beretta group reached 480 million euro in 2011 . Beretta sells to law enforcement agencies through exclusive distributors and peddles its products in its 6 high-end Beretta Gallery stores worldwide. As part of its business, Beretta USA also offers hand-finished firearms and custom-made hunting apparel. Currently, Beretta dominates the competition shotgun market worldwide thanks to the astute integration of traditional walnut material with innovative polymers and revolutionary technologies that enable radically superior performance. The A400 Xcel shotgun, for example, is the culmination of Beretta's lengthy experience in the market and the family's long-lasting passion for shotguns, being awarded as the "2012 Shotgun of the Year" by American Hunter.

\section{Lavazza: Traditional Blending Coffee Transformed to be Served under Extreme Conditions}

Lavazza is an Italian manufacturer of coffee products, founded in Turin in 1895 by Luigi Lavazza as a small grocery store at Via San Tommaso 10, and now managed by the third and fourth generation of the Lavazza family. Lavazza is recognized as the market leader in Italy and among the world leaders in espresso products. Lavazza has a turnover of 1.34 billion euro, 2,700 employees worldwide, a presence in over 90 countries, 4 production plants in Italy and 9 foreign subsidiaries. The firm owes its success to the capability to continuously innovate its products, but still remaining anchored to its traditional specialization in blending coffee. This capability results from the application of a traditional coffee mixing process to obtain flavorful products, which was first invented by Luigi Lavazza in 1910. A recent example is ISSpresso, the first capsulebased espresso system able to work in extreme conditions, even in space.

Sangalli: Milanese Traditional Sewing Applied to High-tech Textiles 
The atelier Sangalli, recently awarded by the Italian Chamber of Fashion for its creativity, represents one of the historical haute couture high fashion spaces in Milan, opened by Maria Sangalli in 1972. In 2005, a change in ownership and management occurred, with Maria's nephew, Federico Sangalli, stepping in as owner and chief designer. Federico directs the atelier determined to preserve the taste of the traditional unique hand-made dress, by interpreting the "made in Italy" in a contemporary world. For example, in 2014, during the Milano Design Week, Federico Sangalli presented a collection of dresses, light bags and accessories made with a fabric that emits light on its own. This collection completely changed the meaning of high fashion items.

\section{Vibram: Shoeless Hiking Tradition Turned into Barefoot Footwear}

Vibram is a 70-year-old Italian family firm based in Northern Italy, world leader in the production of high performance rubber soles for sport, leisure, work, orthopedic and repair footwear, with more than 35 million soles produced per year and a turnover of around 200 million euro. The foundation of the company dates back to the invention and commercialization of the first rubber sole with the famous design called "tank thread" by Vitale Bramani. The firm is still fully controlled by the Bramani family and family members take major roles in the management of the firm. Historically, the Bramani family has always had a strong passion for hiking and nature and pioneered the barefoot phenomenon. In this context, the firm launched FiveFingers, a line of shoes that mimics the look and mechanics of being barefoot. Indeed, the recombination of the Bramani family's values and passion with innovative technologies resulted in a collection of minimalist footwear that completely changed the meaning of mountaineering shoes, making life "a little more memorable with every step you take".

\section{Insert Table 1 about here}




\section{Sources of Past Knowledge}

A first important aspect of ITT refers to the sources from which past knowledge emanates. Two specific sources of past knowledge are especially important in ITT: (1) knowledge pertaining to the tradition of the firm itself, and (2) knowledge pertaining to the tradition of the territory in which the firm is located (Messeni Petruzzelli \& Albino, 2012). Indeed, both firms and geographical areas evolve along distinct trajectories of specialization, thus following a path-dependent process, which strongly relies on past knowledge gained from research and/or practical experience (Nelson \& Winter, 1982). This, in turn, refers to the longstanding tradition and practices of certain communities, also encompassing the wisdom and teachings of these communities that have oftentimes been passed orally from generation to generation (Shils, 1981). Indeed, tradition is strongly characterized by a high degree of cultural and communitarian nature, being anchored in a number of related historic events and how these are interpreted and understood by the various communities (Hibbert \& Huxham, 2011). Therefore, tradition tends to be characterized by a high degree of stickiness, the result of the unique combination of a number of institutional, economic, cultural, and organizational factors (Zahra \& Wright, 2011), which influence individuals' and firms' routines and knowledge bases (Messeni Petruzzelli \& Albino, 2012). Tradition is hence the product of the "accumulated cultural productivity of society" (Ashworth, 1994: 20), which may serve as a key strategic resource upon which building novel economic opportunities (Graham, 2002). By leveraging tradition it is thus possible to re-discover distinctive knowledge, whose adaption to current market needs and expectations may open the door to the creation of unique opportunities for product innovation and, as a consequence, competitive advantage. 
Our illustrative vignettes indicate that some firms actively seek and leverage past knowledge that resides within the firm's tradition. Beretta leverages the firm's longstanding history of fine craftsmanship, enduring experience with old materials used for five centuries and the shared family worship for hunting, evident in the shotgun A400 Xcel. Similarly, development of the Lavazza ISSpresso was possible thanks to the firm's outstanding traditional competencies in blending coffee nurtured over its hundred-year history of excellence. The belief in close contact with nature and the historical values and passion for barefoot hiking that inspired the development of Vibram's FiveFingers project has always been shared by the Bramani family. These examples illustrate the case of an ITT strategy based on temporal search delving into the firm's tradition.

Other examples illustrate ITT strategies that reach into the tradition of the territory in which the firm operates. For instance, Aboca's products originate from the heritage of ancient herbs and production techniques in Valtiberina (Tuscany). Similarly, the product language of Apreamare's 64' Fly gozzo is inspired by the traditional "gozzo sorrentino", a heritage of the Sorrento territory (Campania), and is developed leveraging the manufacturing skills and product signs characterizing over a century of craftsmanship in the Sorrento area. Finally, ancient sewing techniques used in Atelier Sangalli are found in the heritage of the Milanese high fashion tradition.

\section{Forms of Past Knowledge}

The second building block, storage and retrieval of past knowledge, directs attention to the forms of past knowledge within organizations. Well-established taxonomies distinguish codified and tacit forms of knowledge (Cowan et al., 2000). Codified knowledge reduces the costs of transmitting, storing and reproducing such knowledge (Saviotti, 1998; Zack, 1999). 
Conversely, tacit knowledge cannot be easily transferred because it is not expressed in an explicit form (Von Krogh, Ichijo, \& Nonaka, 2000). Codified knowledge in ITT most commonly takes the form of raw materials and manufacturing processes (Benezech et al., 2001; Brusoni, Marsili, \& Salter, 2005). Moreover, past knowledge can be codified in product signs, or combinations of colors, textures, symbols, etc. that communicate messages to product users (Dell'Era \& Verganti, 2007). Differently, tacit knowledge from the past mainly refers to the assumptions and values at the base of an organization's culture in the past. According to Schein (2004), underlying assumptions are unconscious, taken-for-granted beliefs, perceptions, thoughts and feelings, representing the ultimate source of value and actions in an organization.

Our illustrative examples show that family businesses involved in ITT consciously identify and use traditional raw materials to manufacture new products, even if these raw materials are no longer in use. Aboca's products incorporate the properties of ancient herbs. Beretta's A400 Xcel shotgun integrates traditional raw materials with innovative polymers using an extremely advanced technology. The double-pointed hull of Apreamare's gozzo, dating back to Roman boats, is an example of past knowledge codified in the form of shapes and forms. Moreover, past knowledge can be codified in manufacturing processes, such as those involving shipwrights, blacksmiths and carpenters in Apreamare, the production techniques traditionally used in the local tobacco industry in Aboca, Lavazza's traditional coffee blending technique and the old sewing methods of Atelier Sangalli.

Examples of tacit forms of past knowledge include the conviction that human beings and nature are strongly intertwined and co-evolve, and that a sustainable future is only possible by respecting nature, a solid belief shared by all Aboca employees, which inspire all product innovation projects initiated by the firm. Similarly, the Bramani family at the helm of Vibram 
shares values rooted in the belief that the human being is only fully realized in close contact with nature and that complete fulfilment for humans is only possible if barriers that society and economic development have created between man and nature are broken down. These thoughts inspired Vibram when it created the FiveFingers and made it a pioneer in the barefoot walking and running movement worldwide.

\section{Types of Product Innovation}

The third building block is product innovation. Product innovation research suggests that codified and tacit knowledge can be reinterpreted to develop two types of product innovations: (1) innovations that entail offering new functionalities by innovating the technologies on which the product is built; (2) innovations that determine a change in the reason why customers buy a product by innovating its meaning (Verganti, 2008; Veryzer, 1998). The former are innovations involving a deep use of science and technology in developing products with innovative functionalities. This approach assumes a progression of knowledge from basic science to applied research, to the development of products for commercial ends (e.g., Tushman \& Anderson, 1986). Differently, the latter "starts from the comprehension of subtle and unspoken dynamics in sociocultural models and results in proposing radically new [product] meanings and languages that often imply a change in sociocultural regimes" (Verganti, 2011: 387). These types of innovations are exemplified by products such as the Nintendo Wii that completely changed the meaning of console gaming, from passive immersion into a virtual world to a socialization experience stimulating active physical entertainment (Norman \& Verganti, 2013).

The two types of product innovations can both originate from the use of past knowledge. Indeed, old materials or production processes can give birth to new products characterized by highly innovative and rare functionalities (Ahuja and Katila, 2004), which enhance the firm's 
appropriation advantage because this reduces the risks of imitation and misappropriation (Di Minin \& Faems, 2013). At the same time, past knowledge carries a rich set of values and beliefs that can revamp positive feelings and offer existing products with new meanings, thus opening novel market opportunities and making the products able to satisfy new or latent customers' needs (Brown et al., 2003).

Table 2 summarizes the different types of ITT strategies classified as a combination of: (i) sources from which past knowledge is retrieved; (ii) forms of codified and tacit knowledge retrieved from the past; and (iii) types of product innovation enabled by the combination of past knowledge with up-to-date technologies. Table 2 also references our illustrative example firms, which are discussed in detail below.

\section{Insert Table 2 about here}

Beretta's A400 Xcel shotgun, for instance, has superior performance such as reduced recoil, extreme durability and comfortable handling, attained through a skillful integration of old raw materials such as the walnut material. Aboca products combine the properties of ancient and almost forgotten herbs leading to extremely effective drugs without the usual side effects. Lavazza's ISSpresso enables savoring traditional coffee in extreme conditions such as in space by combining traditional coffee blending methods with highly innovative technologies.

In other instances, past knowledge has led to important modifications in the meaning of existing products. Apreamare changed the meaning of "gozzo" from a boat mainly used for commercial fishing into a pleasure-craft. Vibram's FiveFingers originated from the desire to reinterpret the conventional mountain shoe concept, producing hiking shoes that are bought not only for their technical characteristics but also to rediscover the experience of coming into 
contact with nature. Finally, Federico Sangalli changes the meaning of high fashion apparel by incorporating fiber optics in textiles.

\section{Interiorization and Reinterpretation Capabilities Underlying ITT}

The final, and perhaps most important, building block is formed by a specific subset of dynamic capabilities (Teece, 2014), namely the capabilities to interiorize and reinterpret past knowledge. Specifically, interiorization refers to the firm's capability of internalizing, within its organizational boundaries, potentially useful knowledge from the past, by searching and sourcing it from the tradition of the firm or of its territory. On the other hand, we define reinterpretation as the capability of making this knowledge marketable and useful to satisfy contemporary customer needs, by combining selected forms of past knowledge with up-to-date technological solutions.

In terms of interiorization, bringing past knowledge culturally close to employees, especially those involved in the innovation process, is key for ITT (Messeni Petruzzelli \& Savino, 2014). Interiorization capabilities allow past knowledge to be fully understood and reduce the risk of incorrect applications due to forgotten practices, lost records and staff turnover (Argote, 1999). This is attained by ensuring cultural closeness between past knowledge and the inventors, enabling a deep understanding of the value and adoption of these traditional resources in the form of common interpretations and routines which "allow organizations [and individuals] to interpret and give meaning to actions without making all these difficult interpretations explicit" (Knoben \& Oerlemans, 2006: 76). This in turn calls for shared cognitive and interpretative schemes among employees (e.g., Jensen \& Szulanski, 2004), which contribute to sustaining and enhancing their aptitude to effectively use past resources (e.g., Kostova \& Zaheer, 1999). Creating a tight link between past knowledge and the experiences of employees (Maggitti, 
Smith, \& Katila, 2013) emerges therefore as a critical aspect of ITT in that such capabilities allow inventors to absorb and apply past knowledge to develop new products. By creating a sense of cultural proximity between employees and past knowledge embedded in the tradition of the firm or the territory, a firm can internalize such knowledge, identify the appropriate forms in which it can be stored and retrieved, and hence leverage it by reducing the risk of misinterpretation and wrong applications in the product innovation process.

In terms of reinterpretation, integration of past knowledge and its recombination to develop product innovations can unfold through two distinct processes. First, past knowledge may be recombined with technologies from distant industrial fields (Messeni Petruzzelli \& Savino, 2014), hence augmenting the variety and scope of the recombination process (Katila \& Ahuja, 2002; Laursen, 2012). Introducing technologies from different contexts enables the firm to refresh its competence base, thereby avoiding the risk of rendering past knowledge obsolete and enhancing its newness (Ahuja \& Lampert, 2001). Second, past knowledge may be recombined with solutions and technologies that are familiar and largely adopted in the specific industrial field, but used to develop new connections among the various tangible and intangible elements of the product, resulting in unexpected functionalities or meanings (Maggitti, Smith, \& Katila, 2013). This approach allows the creation of successful new products by bringing elements generally considered as isolated and distinct into close proximity (Schilling \& Green, 2011), without damaging product functionality and meaning (Fleming, 2001).

To summarize, ITT requires interiorizing knowledge sourced from the past, ensuring that this knowledge is stored in forms that are culturally close to the organization and its employees, and recombining the selected forms of knowledge with technologies from different industries or with technologies already applied in the same industrial field but used to create unexpected 
functionalities and meanings. According to Teece's (2014) framework, these should be conceived as a particular subset of dynamic capabilities tailored to a specific approach to gain competitive advantage, i.e., leveraging past knowledge to develop product innovations.

Among our examples, the Aboca Museum and the "Bibliotheca Antiqua" illustrate how historians and researchers are enabled to interiorize the tradition of the territory where the officinal herbs are cultivated, including its history and culture. Moreover, ad hoc training courses and a variety of symbols in the headquarters and production sites are used to spread and share knowledge about the properties of traditional officinal herbs. To guarantee the interiorization of Sorrento's nautical experience in Apreamare, the founding family employs local shipwrights, blacksmiths and carpenters to leverage their skills and understanding of the ancient boat manufacturing process used to develop new products. To ensure new employees are culturally close to the firm's traditional coffee blending process, Lavazza established a Training Centre Network, the world's largest coffee school with eight sites in Italy and fifty abroad, with the goal of disseminating understanding and the Lavazza espresso culture by training and educating employees and other stakeholders.

Reinterpretation capabilities are also well exemplified by our illustrative vignettes. Lavazza illustrates the reinterpretation of past knowledge by combining it with distant advanced technologies such as those from the space industry used to develop the first espresso machine able to work in space. Sangalli maintains the old high fashion division of labor, where the tailors sew each item from beginning to the end, sitting at the same table under the leadership of the "premiere", the oldest tailor of the team who has the role of training newly hired tailors in their first two-years in the firm. In this way, Sangalli combines the old Milanese high fashion heritage with very distant technologies such as fiber optics used in the telecommunication industries to 
give unexpected meanings to high fashion apparel and items. Similarly, Beretta's commitment to nurture generations of craftsmen in the production facility enables to leverage past knowledge and recombine it with the most advanced material and production technologies in the firearm industry. Aboca, Apreamare and Vibram illustrate reinterpretation capabilities that enable to recombine past knowledge with technologies that are familiar and largely adopted in the specific industrial field. Aboca recombines ancient officinal herbs with biotech and leading edge manufacturing techniques widely applied in the pharmaceutical industry. Apreamare's yachts recombine the shape and form of the traditional "gozzo sorrentino" with modern engine and boat manufacturing technologies. Finally, Vibram reinterprets the basic assumptions and beliefs of the mountaineering shoe by using avant-garde rubber material to manufacture footwear, delving into the traditional values and beliefs of the founding family and their love for barefoot walking.

\section{DIRECTIONS FOR FUTURE RESEARCH}

The ITT framework presented and discussed above challenges existing assumptions about past knowledge in innovation management research and practice, and galvanizes future research attention on ITT as a viable and effective innovation strategy that can contribute to the firms' competitive advantage. Our examination of diverse literatures and conceptual analysis suggest that we still need theoretical development and specific studies on each building block. These research gaps raise opportunities for future research on family business and innovation management on the antecedents and performance implications of ITT. These research gaps and related questions for future research are summarized in Table 3 and discussed below.

\section{Insert Table 3 about here}

\section{Research Gaps and Related Research Questions}


Sources of past knowledge. Opportunities exist for addressing the varying sources of past knowledge as well as for improving our understanding of how tradition originates and evolves over time, how firms and industries contribute to create and change firm and territory traditions, and the role of national, regional and organizational culture.

Relatedly, the two specific sources of past knowledge that emerge from existing innovation management research are not always independent from one another. For example, Beretta's multi-centennial presence and prominent role in the socio-economic development of its home town created a clear overlap between the tradition of the firm and that of the territory, as exemplified by the Italian major Firearms and Weapon-making Tradition Museum located in Gardone Val Trompia. Therefore, future research should explore the links between tradition that originates from different sources, including not only firms and territories, but also the controlling family and individuals working in organizations and living in certain territories, as well as their mutual influences, and the role of family and non-family firms in navigating the different sources of past knowledge. Finally, similar to other sources of knowledge (e.g., geographically and technologically distant contexts), searching past knowledge is subject to decreasing marginal returns (Katila, 2002; Katila \& Ahuja, 2002), hence future research is needed to assess to what extent searching past knowledge is beneficial, along with its costs and potential drawbacks. In this regard, scholars may also investigate to what extent such marginal returns differ between family and non-family firms, hence increasing our understanding of the family businesses' capability to innovate through tradition.

Research Gap 1: Research on ITT should address the varying sources of past knowledge and how tradition originates and evolves over time, including the role of family and nonfamily firms.

Research Gap 2: Research on ITT should clarify the relationships between firm tradition and territory tradition, including the role of family owners and managers. 
Research Gap 3: Research on ITT should not assume that searching for past knowledge is always beneficial or detrimental for innovation. Rather, it should identify optimum levels of past knowledge search, taking into account the marginal benefits and costs of searching past knowledge, as well as the contingency factors that cause such benefits and costs to prevail. Specifically, the differences between family and non-family firms need to be explored.

Forms of past knowledge. Little attention has been devoted to understanding the distinctive forms that past knowledge can take in an organization. Among the few exceptions, Schein (2004) pointed to some unique attributes of past knowledge that can take the form of unconscious assumptions, beliefs, perceptions, thoughts and feelings. At the same time, our illustrative examples suggest that past knowledge can take a variety of tangible and intangible forms, opening up promising opportunities for future research. For example, future research is needed to explore different ways in which firms store and retrieve past knowledge, how firms manage stocks and flows of past knowledge, and whether different forms of past knowledge exist at different levels, such as individuals, groups and organizations. Examining how such storage and retrieval differs across family firms at different generations of family control and how stored knowledge is handed down across generations of family control also warrant exploration.

Future research should also attempt to gain deeper understanding of the intellectual property issues associated with past knowledge. The questions of whether (or under which conditions) formal intellectual protection of knowledge encourages innovation or imposes legal risks and burdens that limit innovation has been subject to a lively debate (e.g., Bessen and Meurer, 2008). Research can fruitfully broaden this understanding by exploring and comparing the different challenges that present and past knowledge involve in terms of intellectual property protection, in family and non-family firms. 
Research Gap 4: Research on ITT should address the varying forms that past knowledge takes in organizations, and the flow of such knowledge, also referring to how such flow occurs across generations in family firms.

Research Gap 5: Research on ITT should explore how family and non-family firms protect and manage the intellectual property of past knowledge.

Types of product innovation. Prior research and our illustrative examples suggest that past knowledge can contribute to innovation of both product functionalities and meanings. However, more research is needed to explain to what extent past knowledge is conducive to superior innovation performance, alone or in combinations with other forms of knowledge. Further, there is a need to examine to what extent searching past knowledge is beneficial and whether temporal search is exposed to the "too much of a good thing" effect (e.g., De Dreu, 2006). Indeed, relying upon the past may also present a double-edged sword effect, especially when firms are unable to reinterpret tradition, thus offering only a conservative application of past knowledge, without any effort to adapt it to changing market conditions. For example, this problem is illustrated by the Italian company Natuzzi, a manufacturer of sofas, armchairs and living room accessories, which has experienced a significant downturn due to the excessive reliance on its traditional resources (e.g., product signs and materials), which were no longer appropriate in light of the changing nature of the competitive scenario. Also, future work is needed to understand whether there are different performance implications between innovations of functionality and meaning based on past knowledge, in what circumstances one or the other type of innovation results in higher/lower innovation performance, as well as comparing if and how family firms differ from their non-family counterparts in developing innovations exploiting past functionalities and meanings. Accordingly, an interesting direction for future research would be to study when and under what circumstances tradition, both of the firm and of its territory, 
should be forgotten rather than leveraged. Moreover, the boundaries of the ITT framework should be examined thoroughly in future research to understand whether and to what extent past knowledge benefits different types of innovations (e.g., service, process, organizational, business model innovation), and in which way (e.g., continuous/discontinuous, incremental/radical, sustaining/disruptive, flexible/inflexible innovations). These different types and modes of innovation may present different types of challenges in the use of ITT. These aspects represent central issues toward a deeper understanding of ITT and its effects on innovation performance.

Research Gap 6: Research on ITT should investigate the (non-linear) effects of past knowledge on innovation performance in family and non-family firms.

Research Gap 7: Research on ITT should extend the boundaries of the ITT model in family and non-family firms in the context of other types of innovation.

ITT Capabilities. Drawing from prior research on dynamic capabilities, we have developed initial insights pointing to the importance and nature of interiorization and reinterpretation to leverage past knowledge in developing product innovations. However, there are several opportunities for further research, particularly exploring the micro-foundations of ITT capabilities. According to Coleman (1990), studying the micro-foundations of social systems is key to understanding them. Thus, the micro-foundations of ITT represent important research areas for gaining a deep understanding of its antecedents. For example, such research may focus on the role of individual cognitions and their interactions within organizations. Research should also look at specific patterns of communication in firms and territories, the role of structures for knowledge management such as communities of practice and knowledge gatekeepers in discovering the trail of past knowledge through the firm and territory. Appreciating how organizational routines, histories, stories, documentation, and procedures (Pentland \& Feldman, 2005) concur in creating shared understandings of knowledge at the organization level and in 
interiorizing and reinterpreting past knowledge is another area worth of future investigation. Research also appears warranted that examines more in depth the relationships among the building blocks of the ITT framework to gain a better understanding of how interiorization capabilities relate different sources of past knowledge to forms of past knowledge, and how reinterpretation capabilities transform different forms of past knowledge into product innovations. Future research on the relationships among the different building blocks of ITT might suggest, for example, that only some forms of past knowledge are conductive to innovation of product functionalities, whereas other forms of past knowledge are more likely to lead to innovation of product meaning. Finally, as for other dynamic capabilities (Teece, 2014), we assume that firms have heterogeneous ITT capabilities. Moreover, we noted earlier that family firms are recognized as a particularly diverse form of organization (e.g., Chua et al., 2012; Wright et al., 2014). Therefore, examining the factors that differentiate family and non-family firms in terms of ITT capabilities as well as the drivers of heterogeneity in ITT capabilities among family firms represent promising areas for future research. To do so, future research can systematically examine managerial, organizational and inter-organizational factors, as well as compare family and non-family firms or different types of family firms based, for example, on their diverse goals (Kotlar \& De Massis, 2013), governance structures (Wilson, Wright, \& Scholes, 2013) and firm age (De Massis, Chirico et al., 2014). Scholars are therefore encouraged to adopt a more contextualized approach that is able to recognize the sources and contextual elements of the heterogeneity of family firms (Wright et al., 2014), thus enabling a more finegrained understanding of how differences in family firm characteristics affect their willingness and ability to engage in ITT (De Massis, Di Minin \& Frattini, 2015). 
Finally, future research needs to examine how ITT capabilities evolve over time, including path- and place-dependencies and cumulative knowledge creation (Heimeriks and Boschma, 2013), and the role of situational factors that may disrupt such trends, such as succession and generational transfer of businesses. Which managerial decisions (Dosi, Faillo, \& Marengo, 2008) and micro-foundations (Felin et al., 2012) help create and nurture these capabilities in family (and also non-family) businesses remains an open question and points to a promising area for future research.

Research Gap 8: Research on ITT should investigate the micro-foundations of ITT capabilities in family and non-family firms.

Research Gap 9: Research on ITT should clarify the relationships between sources of past knowledge, forms of past knowledge and product innovation, in both family and non-family firms.

Research Gap 10: Research on ITT should explore the drivers of heterogeneity and variation of ITT capabilities between family and non-family firms and among different types of family firms.

Contextual factors. Future research is needed to explore the role of external factors in influencing the availability of past knowledge and the firms' capability to interiorize and reinterpret such knowledge in product innovation. As noted earlier, it appears that past knowledge can be particularly valuable in specific industries where customers' needs are enduring (Hargadon \& Douglas, 2001). However, more research is needed to identify whether ITT is more viable in those industries, and why. More broadly, theoretical and practical understanding of ITT will be improved if future research examines the role of the economic, social, political, legal, cultural, spatial and technological environments (i.e., the exo-context) in enabling or constraining the use of past knowledge to innovate. By doing so, future research will ideally enable the identification of the mechanisms and junctures through which the past becomes an important source of innovation in relatively younger family firms, as well as what 
types of policies may better support firms in leveraging the past and use it to develop new products.

Future research on the role of the chrono-context is also warranted because temporal factors such as global and national crises can shape significantly customers' needs, creating nostalgia (Brown et al., 2003), thereby increasing the perceived value of new products that embed past knowledge. Thus, it is likely that temporal factors such as crises can have an effect on the viability of ITT, which emerges as a further avenue for future research. Such research could include examination of the differences in response nature and speed between family and non-family firms in their use of ITT in relation to changes in the chrono-context.

In addition to the research opportunities discussed above, our analysis stimulates future research to empirically validate and generalize our theoretical assertions. In particular, it would be interesting to address, for instance, through large-scale representative surveys, how many family firms engage in ITT compared to non-family firms. Further, as our examples are drawn from the Italian context, it would also be appropriate to conduct such surveys in different institutional contexts since family and non-family firms differ between contexts (Wright et al., 2014).

Finally, as largely discussed, an ITT strategy might also be applied by non-family firms. Indeed, managers of non-family companies can learn to emulate these extremely successful family businesses and focus on specific forms of past knowledge to build a sustainable competitive advantage. This view is corroborated by examples of non-family businesses that appear to have the capability to use past knowledge to innovate, pointing to the viability of the ITT strategy outside the family business domain. For example, the US multinational conglomerate General Electric deploys this potential through the application of purposefully 
designed organizational routines that enable continuously generating technological innovations by leveraging the firm's tradition. GE's DDHF multistage centrifugal pump, for example, was based on the company's traditional hydraulic design but was re-engineered for $\mathrm{CO} 2$ pumping and enhanced oil recovery. Another well-known example is Cartier, which has largely based its competitive advantage on its capability to develop luxury products by blending cutting-edge technologies and the traditional craftsmanship of local artisans. The success of Cartier's watch production is due to the Swiss watch-making tradition and expertise that the company still preserves and nurtures through its watch-making school, the Institut Horlogerie Cartier. Therefore, these exemplar cases suggest the extension of the ITT concept and the related benefits outside the realm of family business, calling for future investigation in this direction. Indeed, our analysis provides insights for considering ITT as a viable strategy for non-family businesses and adds to the emerging stream of studies identifying the management practices that non-family firms can learn from family businesses (Kachaner, Stalk, \& Block, 2012). More specifically, the application of ITT can take on dissimilar forms and significance among different types of nonfamily firms. For example, the way and the extent to which an ITT strategy can be applied may differ across widely-held corporations, cooperative ventures, joint ventures, venture capitalbacked firms or state-owned firms. Clearly, a key assumption for the successful application of ITT is the existence of specific tradition that can be leveraged. The ideas we have presented are therefore more difficult to apply for firms that are too young to borrow from their past tradition or are not particularly linked to the tradition of any specific territory (e.g., newly established multinational subsidiaries).

Research Gap 11: Research on ITT should incorporate the effects of exo-context and chrono-context, and empirically validate and generalize the ITT model comparing family and non-family firms. 
Research Gap 12: Research on ITT should investigate the managerial practices that nonfamily firms adopt to implement the ITT strategy, also studying differences occurring among different types of non-family firms.

\section{CONCLUDING DISCUSSION}

Drawing upon a diverse body of research, our study develops and conceptualizes a new product innovation strategy, called innovation through tradition (ITT), through which firms can leverage knowledge from the past to develop new product functionalities and meanings. The concept of ITT can be decomposed into its key building blocks: (i) the sources of past knowledge, distinguishing between knowledge pertaining to the tradition of the firm itself or of its territory, (ii) the forms of past knowledge, in terms of codified (raw materials, product signs, manufacturing processes) and tacit (assumptions, values, beliefs) ones, (iii) the type of product innovation strategy enacted by leveraging on knowledge from the past, i.e. innovation of product functionalities or innovation of product meaning, and (iv) the key capabilities underlying ITT, i.e. interiorization and reinterpretation, which allow the assimilation and sharing of past knowledge stocks across the organization and the combination of these with up-to-date technologies to generate product innovation. These building blocks have been illustrated by using examples from six long-lasting and innovative family firms that have mastered ITT and used tradition to innovate their products. Indeed, family businesses appear to be in a privileged position for leveraging tradition to innovate, since their inner nature offers opportunities to establish, maintain, and nurture links with past. Therefore, this makes family firms an excellent context where elucidating those capabilities underlying the ITT strategy, and identifying managerial practices and solutions that may be learned by non-family companies for successfully innovate through the past.

\section{Implications for Research}


We identified above a number of specific research gaps relating to ITT but our analysis also holds a number of more general implications for management research. First, this paper suggests a way of reconciling the innovation paradox that characterizes innovation in family businesses (Chrisman et al., 2015), whereby these firms are often unwilling to engage in innovation because the family wishes to maintain control, preserve its identity and behave parsimoniously, despite having the resources and capabilities to do so. By delving into the firm's tradition and that of its territory, family businesses can overcome this innovation paradox and engage in successful product innovation.

Second, our research contributes to studies conceptualizing innovation as a search process (Savino et al., 2015), unveiling the merits of searching over time to identify valuable sources of innovation, thus providing further arguments against the conventional management prescription of dismissing the old to make way for the new. We add, therefore, to the recombinant view of the innovation process (Ahuja et al., 2008). Existing research has studied two dimensions of the search process in innovation, i.e., search depth and search breadth. We point to the importance of considering a further dimension of search processes in innovation, i.e., temporal search.

Third, we contribute to innovation research by integrating knowledge search and recombination perspectives and by suggesting that, besides technologies and the market, past knowledge is another important source for innovating product functionalities and meanings (Messeni Petruzzelli \& Savino, 2014).

Fourth, our study adds to the literature on entrepreneurship and enterprise development (Acs \& Audretsch, 1990; Lumpkin, Steier, \& Wright, 2011; Simsek \& Heavey, 2011). Indeed, ITT is a product innovation strategy based on a non-costly, highly idiosyncratic resource, i.e., the 
tradition of the firm or of its territory. This resource can determine strong competitive advantages in both the value creation and capture phases of the innovation process, without requiring high financial resource commitments. ITT could therefore foster the development of small- and medium-sized firms, which are strongly embedded in their territory and help them compete against larger, multinational enterprises.

Fifth, this study contributes to research on dynamic capabilities (Eisenhardt \& Martin, 2000) by showing that this model can be used to explain the dynamics underlying an important source of sustained enterprise performance, i.e., product innovation. Our study highlights two capabilities underlying ITT, namely, interiorization and reinterpretation. These should be conceived as a particular subset of dynamic capabilities tailored to a specific approach to gain competitive advantage, i.e., leveraging past knowledge to develop product innovations (Teece, 2014).

Finally, also with respect to strategy, our paper informs research on absorptive capacity (Zahra \& George, 2002), showing the relevance of a temporal view and offering new insights for the investigation of processes sustaining the effective absorption of traditional resources.

\section{Implications for Practice}

Our study has also a number of interesting managerial implications. First, managers with responsibilities for product innovation are cautioned against the often-claimed need to establish a corporate sense of urgency and obtain a mandate to dismiss the past and open the door to the future. Instead, we highlight the critical role played by a firm's tradition and that of its territory to provide a source of raw materials, product signs, manufacturing processes, assumptions and beliefs that can be transformed into new products. ITT enables firms to re-discover and renovate past knowledge and create products with new functionalities and meanings. 
Second, we also offer managers some preliminary insights into the capabilities underlying ITT, which we call interiorization and reinterpretation. Future research will have to systematically identify the managerial decisions underlying these capabilities, but it is possible to argue here that some practices and routines can be used to foster the capability to interiorize and reinterpret temporally distant knowledge by permeating the culture of the entire organization and allowing those involved in the innovation process to understand the strategic importance of the past, searching within it and transforming it into new product functionalities and meanings. Some practices may include historical narratives to maintain links to the firm's or its territory's past based on different types of internal and external communications, ancestor symbolization that call to mind the firm's or its territory's past, emotion elicitation to create events that build socio-emotional attachment to the firm's or its territory's tradition, and legacy councils to establish working governing bodies responsible for designing policies and initiatives aimed at preserving the firm's or its territory's past. These practices are more naturally applied in longlasting and innovative family firms, but they can be emulated by managers of non-family firms to revitalize their organization's capability to leverage past knowledge to innovate.

\section{Conclusion}

Long-lasting innovative family firms like Aboca, Apreamare, Beretta, Lavazza, Sangalli and Vibram show that the past should not be considered a core rigidity, but an opportunity to discover knowledge to be turned into new products. ITT is a product innovation strategy that addresses the recency bias in innovation management and allows to deploy new product functionalities and meanings based on the interiorization and reinterpretation of knowledge rooted in the past of the firm or of its territory. This paper has laid the foundations for a deeper understanding of innovation through tradition and the building blocks of this new concept in the 
innovation literature. We hope it will inspire other scholars to continue this important and promising area of investigation, where we have only started to scratch the surface. 


\section{REFERENCES}

Acs, Z. J., \& Audretsch, D. B. (1990). Innovation and small firms. MIT Press.

Adner, R., \& Snow, D. (2010). Old technology responses to new technology threats: Demand heterogeneity and technology retreats. Industrial and Corporate Change, XIX(5), 16551675.

Ahuja, G., \& Katila, R. (2004). Where do resources come from? The role of idiosyncratic situations. Strategic Management Journal, XXV(8-9), 887-907.

Ahuja, G., \& Lampert, C. M. (2001). Entrepreneurship in the large corporation: A longitudinal study of how established firms create breakthrough inventions. Strategic Management Journal, XXII(6-7), 521-543.

Ahuja, G., Lampert, C. M., \& Tandon, V. (2008). Moving beyond Schumpeter: Management research on the determinants of technological innovation. Academy of Management Annals, II(1), 1-98.

Argote, L. (1999). Organizational learning: Creating, retaining and transferring knowledge. Kluwer: Boston.

Arora, A., Gmbardella, A., Magazzini, L., \& Pammolli, L. (2009). A breadth of fresh air? Firm type, scale, scope, and selection effects in drug development. Management Science, $L V(10), 1638-1653$.

Ashworth, G. J. (1994) From history to heritage — from heritage to history: in search of concepts and models, in: Ashworth, G. J., \& Larkham, P. J. (Eds.) Building a New Heritage: Tourism, Culture and Identity in the New Europe. Routledge: London. 
Banbury, C., \& Mitchell, W. (1995). The effect of introducing important incremental innovations on market share and business survival. Strategic Management Journal, XVI(1), 161-182.

Barney, J. (1991). Firm resources and sustained competitive advantage. Journal of Management, XVII(1), 99-120.

Barron, D. N., West, E., \& Hannan, M. T. (1994). A time to grow and a time to die: growth and mortality of credit unions in New York City, 1914-1990. American Journal of Sociology, $C(2), 381-421$.

Benezech, D., Lambert, G., Lanoux, B., Lerch, C., Loos-Barion, J. (2001). Completion of knowledge codification: An illustration through the ISO 9000 standards implementation process. Research Policy, $X X X(9), 1395-1407$.

Bessen, J., \& Meurer, M. J. (2008). Do patents perform like property? Academy of Management Perspectives, $X X I I(3), 8-20$.

Brown, S. (2001). The retromarketing revolution: l'imagination au pouvoir. International Journal of Management Reviews, III(4), 303-320.

Brown, S., Kozinets, R. V., \& Sherry Jr. (2003). Teaching old brands new tricks: retro branding and the revival of brand meaning. Journal of Marketing, LXVII(3), 19-33.

Brusoni, S., Marsili, O., \& Salter, A. (2005). The role of codified sources of knowledge in innovation: Empirical evidence from Dutch manufacturing. Journal of Evolutionary Economics, $X V(2), 211-231$.

Calantone, R. J., Chan, K., \& Cui, A. S. (2006). Decomposing product innovativeness and its effects on new product success. Journal of Product Innovation Management, XXIII(5), 408-421. 
Capaldo, A., Lavie, D., \& Messeni Petruzzelli, A. (2014). Knowledge maturity and the scientific value of innovations: the roles of knowledge distance and adoption. Journal of Management, in press.

Chrisman, J. J., \& Patel, P. J. (2012). Variations in R\&D investments of family and non-family firms: Behavioral agency and myopic loss aversion perspectives. Academy of Management Journal, LV(4), 976-997.

Chrisman, J. J., Chua, J. H., De Massis, A., Frattini, F., \& Wright, M. (2015). The ability and willingness paradox in family firm innovation. Journal of Product Innovation Management, XXXII(3), 310-318.

Chua, J. H., Chrisman, J. J., \& Sharma, P. (1999). Defining the family business by behavior. Entrepreneurship: Theory and Practice, XXIII(4), 19-39.

Chua, J. H., Chrisman, J. J., Steier, L. P., \& Rau, S. B. (2012). Sources of heterogeneity in family firms: An introduction. Entrepreneurship Theory and Practice, XXXVI(6): 1103-13.

Coleman, J. S. 1990. Foundations of Social Theory. Cambridge, MA: Belknap.

Cowan, R, David, P. A., \& Foray, D. (2000). The explicit economics of knowledge codification and tacitness. Industrial and Corporate Change, IX(2), 211-253.

De Dreu, C. K. W. (2006). When too little or too much hurts: Evidence for a curvilinear relationship between task conflict and innovation in teams. Journal of Management, XXXII(1), 83-107.

de Janasz, S. C., Sullivan, S. E., \& Whiting, V. (2003). Mentor networks and career success: Lessons for turbulent times. Academy of Management Perspectives, XVII(4), 78-91. 
De Massis A., Chirico F., Kotlar J., \& Naldi L. (2014). The temporal evolution of proactiveness in family firms: The horizontal s-curve hypothesis. Family Business Review, XXVII(1), $35-50$.

De Massis A., Di Minin A., \& Frattini F. (2015). Family-driven innovation: Resolving the paradox in family firms. California Management Review, LVIII(1), 5-19.

De Massis, A., Kotlar, J., Chua, J. H., \& Chrisman, J. J. (2014). Ability and willingness as sufficiency conditions for family-oriented particularistic behavior: Implications for theory and empirical studies. Journal of Small Business Management, LII(2), 344-364.

De Massis, A., Kotlar, J., Frattini, F., Chrisman, J., Nordqvist, M. (2016). Family governance at work: Organizing for new product development in family SMEs. Family Business Review, in press.

De Massis, A., Sharma, P., Chua, J. H., Chrisman, J. J., \& Kotlar, J. (2012). State-of-the-art of family business research. In A. De Massis, P. Sharma, J. H. Chua, \& J. J. Chrisman (Eds.), Family Business Studies: An Annotated Bibliography. Northhampton, MA: Edward Elgar.

Dell'Era, C., \& Verganti, R. (2007). Strategies of innovation and imitation of product languages. Journal of Product Innovation Management, XXIV(6), 580-599.

Di Minin, A., \& Faems, D. (2013). Building appropriation advantage: An introduction to the special issue on intellectual property management. California Management Review, $L V(4), 7-14$. 
Dosi, G., Faillo, M., \& Marengo, L. (2008). Organizational capabilities, patterns of knowledge accumulation and governance structures in business firms: An introduction. Organization Studies, XXIX(8-9), 1165-1185.

Duran, P., Kammerlander, N., van Essen, M., \& Zellweger, T. (2015). Doing more with less: Innovation input and output in family firms. Academy of Management Journal, in press.

Eisenhardt, K. M., \& Martin, J. A. (2000). Dynamic capabilities: What are they? Strategic Management Journal, XXI(10-11), 1105-1121.

Felin, T., Foss, N. J., Heimeriks, K. H., \& Madsen, T. L. (2012). Microfoundations of routines and capabilities: individuals, processes, and structure. Journal of Management Studies, $X \operatorname{LIX}(8), 1351-1374$.

Fleming, L. (2001). Recombinant uncertainty in technological search. Management Science, $X L V I I(1), 117-132$.

Gagné, M., Sharma, P., \& De Massis, A. (2014). The study of organizational behavior in family business. European Journal of Work and Organizational Psychology, XXIII(5): 643656.

Glaser, B., \& Strauss, A. (1967). The Discovery of Grounded Theory: Strategies in Qualitative Research. Wiedenfeld and Nicholson: London.

Gómez-Mejía, L. R., Haynes, K. T., Núñez-Nickel, M., Jacobson, K. J. L., \& Moyano-Fuentes, J. (2007). Socioemotional wealth and business risks in family-controlled firms: Evidence from Spanish olive oil mills. Administrative Science Quarterly, LII(1), 106-137.

Graham, B. (2002). Heritage as knowledge: Capital or culture? Urban Studies, XXXIX(5-6), 1003-1017. 
Gupta, A. K., Smith, K. G., \& Shalley, C. E. (2006). The interplay between exploration and exploitation. Academy of management Journal, IL(4), 693-706.

Hargadon, A. B., \& Douglas, Y. (2001). When innovations meet institutions: Edison and the design of electric light. Administrative Science Quarterly, XLVI(3), 476-501.

Heeley, M. B., \& Jacobson, R. (2008). The recency of technological inputs and financial performance. Strategic Management Journal, XXIX(7), 723-744.

Heimeriks, G., \& Boschma, R. 2013. The path-and place-dependent nature of scientific knowledge production in biotech 1986-2008. Journal of Economic Geography, in press.

Helfat, C. E., \& Peteraf, M. A. (2003). The dynamic resource-based view: capability lifecycles. Strategic Management Journal, XXIV(10), 997-1010.

Henderson, R. M., \& Clark, K. B. (1990). Architectural innovation: the reconfiguration of existing product technologies and the failure of established firms. Administrative Science Quarterly, $X X X V(1), 9-30$.

Hibbert, P., \& Huxham, C. (2010). The past in play. Organization Studies, XXXI(5), 525-554.

Hibbert, P., \& Huxham, C. (2011). The carriage of tradition: Knowledge and its past in network contexts. Management Learning, XLII(1), 7-24.

Jensen, R., \& Szulanski, G. (2004). Stickiness and the adaptation of organizational practices in cross-border knowledge transfers. Journal of International Business Studies, $X X X V(6)$, 508-523.

Kachaner, N., Stalk, G., \& Bloch, A. (2012). What you can learn from family business. Harvard Business Review, XC(11), 103-06. 
Kanter, R. M. (1995). Thriving locally in the global economy. Long Range Planning, XXVIII(6), $130-131$

Katila, R. (2002). New product search over time, past ideas in their prime? Academy of Management Journal, XLV(5), 995-1010.

Katila, R., \& Ahuja, G. (2002). Something old, something new: A longitudinal study of search behavior and new product introduction. Academy of Management Journal, XLV(6), 1183-1194.

Khaire, M., \& Wadhwani, R. D. (2010). Changing landscapes: the construction of meaning and value in a new category - modern Indian art. Academy of Management Journal, LIII(6), $1281-1305$.

Knoben, J., \& Oerlemans, L. A. (2006). Proximity and inter organizational collaboration: A literature review. International Journal of Management Reviews, VIII(2), 71-89.

Kostova, T., \& Zaheer, S. (1999). Organizational legitimacy under conditions of complexity: The case of the multinational enterprise. Academy of Management Review, XXIV(1), 64-81.

Kotlar J., \& De Massis A. (2013). Goal setting in family firms: Goal diversity, social interactions, and collective commitment to family-centered goals. Entrepreneurship Theory \& Practice, XXXVII(6), 1263-1288.

Kotlar, J., Fang, H., De Massis, A., \& Frattini, F. (2014). Profitability goals, control goals, and the R\&D investment decisions of family and non-family firms. Journal of Product Innovation Management, XXXI(6), 1128-1145.

Inglehart, R., Baker, W. E. (2000). Modernization, cultural change, and the persistence of traditional values. American Sociological Review, LXV(1), 19-51. 
Laursen, K. (2012). Keep searching and you'll find: What do we know about variety creation through firms' search activities for innovation? Industrial and Corporate Change, $X X I(5), 1181-1220$.

Laursen, K., \& Salter, A. (2006). Open for innovation: The role of openness in explaining innovation performance among UK manufacturing firms. Strategic Management Journal, XXVII(2), 131-150.

Le Breton-Miller, L., \& Miller, D. (2008). Why do some family businesses out-compete? Governance, long-term orientations, and sustainable capability. Entrepreneurship Theory \& Practice, $X X X(6), 731-746$.

Leonard-Barton, D. (1992). Core capabilities and core rigidities: A paradox in managing new product development. Strategic Management Journal, XII(S1). 111-125.

Lumpkin, G. T., Steier, L., \& Wright, M. (2011). Strategic entrepreneurship in family business. Strategic Entrepreneurship Journal, V(4), 285-306.

Maggitti, P. G., Smith, K. G., \& Katila, R. (2013). The complex search process of invention. Research Policy, XLII(1), 90-100.

Messeni Petruzzelli, A., \& Albino, V. (2012). When Tradition Turns Into Innovation. How Firms Can Create and Appropriate Value Through Tradition. Woodhead Publishing Limited: Oxford.

Messeni Petruzzelli, A., \& Savino, T. (2014). Search, recombination, and innovation: lessons from the haute cuisine. Long Range Planning, XLVII(4), 224-238. 
Messeni Petruzzelli, A., Rotolo, D., \& Albino, V. (2012). The impact of old technologies on innovation: the case of US biotechnology industry. Technology Analysis \& Strategic Management, XXIV(5), 453-466.

Miller, D., \&. Le Breton-Miller, I. (2005). Managing for the Long Run. Harvard Business School Press: Boston.

Miner, A. S., Bassof, P., \& Moorman, C. (2001). Organizational improvisation and learning: A field study. Administrative Science Quarterly, XLVI(2), 304-337.

Nelson, R., \& Winter, S. (1982). An Evolutionary Theory of Economic Change. Harvard University Press: Boston.

Nerkar, A. (2003). Old is gold? The value of temporal exploration in the creation of new knowledge. Management Science, XLIX(2), 211-229.

Norman, D. A., \& Verganti, R. (2013). Incremental and radical innovation: Design research vs. technology and meaning change. Design Issues, $X X X(1)$, 78-96.

Patel, P. C., \& Chrisman, J. J. (2014). Risk abatement as a strategy for R\&D investments in family firms. Strategic Management Journal, XXXV(4), 617-627.

Pentland, B. T., \& Feldman, M. S. (2005). Organizational routines as a unit of analysis. Industrial and Corporate Change, XIV(5), 793-815.

Rosenkopf, L., \& Almeida, P. (2003). Overcoming local search through alliances and mobility. Management Science, XLIX(6), 751-766.

Ryder, B. (2014). Second wind. Some traditional businesses are thriving in an age of disruptive innovation. The Economist, $14^{\text {th }}$ June. 
Savino, T., Messeni Petruzzelli, A. \& Albino, V. (2015), Search and recombination process to innovate: A review of the empirical evidence and a research agenda. International Journal of Management Reviews, in press.

Saviotti, P. P. (1998). On the dynamics of appropriability, of tacit and of codified knowledge. Research Policy, XXVI(7-8), 843-856.

Schein, E. H. (2004). Organizational Culture and Leadership. John Wiley \& Sons: New York.

Schilling, M. A., \& Green, E. (2011). Recombinant search and breakthrough idea generation: An analysis of high impact papers in the social sciences. Research Policy, XL(10), 13211331.

Shils, E. (1981). Tradition. University of Chicago Press: Chicago.

Siggelkow, N. (2007). Persuasion with case studies. Academy of Management Journal, L(1), 20-24.

Simsek, Z., \& Heavey, C. (2011). The mediating role of knowledge-based capital for corporate entrepreneurship effects on performance: A study of small-to-medium-sized firms. Strategic Entrepreneurship Journal, V(1), 81-100.

Sorensen, J., \& Stuart, T. (2000). Aging, obsolescence, and organizational innovation. Administrative Science Quarterly, XLV(1), 81-112.

Strauss, A., \& Corbin, J. (1998). Basics of Qualitative Research, Grounded Theory Procedures and Techniques. Sage: Newbury Park, CA.

Stuart, T. E., \& Podolny, J. M. (1996). Local search and the evolution of technological capabilities. Strategic Management Journal, XVII(S1), 21-38. 
Tapies, J., \& Ward, J. L. (2008). Family Values and Value Creation: Fostering the Enduring Values Within Family-Owned Businesses. New York, NY: Palgrave, Macmillan.

Teece, D. J. (2014). The foundations of enterprise performance: dynamic and ordinary capabilities in an (economic) theory of firms. Academy of Management Perspectives, XXVIII(4), 328-352.

Teece, D. J. (1986). Profiting from technological innovation: Implications for integration, collaboration, licensing and policy. Research Policy, XV(6), 285-305.

Teece, D. (2006). Reflections on profiting from innovation. Research Policy, XXXV(8), 11311146.

Teece, D. J. (2007). Explicating dynamic capabilities: The nature and microfoundations of (sustainable) enterprise performance. Strategic Management Journal, XXVIII(13), 13191350 .

Tushman, M.L., \& Anderson, P. (1986). Technological discontinuities and organizational environments. Administrative Science Quarterly, XXXI(3), 439-465.

Verganti, R. (2008). Design, meanings and radical innovations: A metamodel and a research agenda. Journal of Product Innovation Management, XXV(5), 436-456.

Verganti, R. (2011). Radical design and technology epiphanies: A new focus for research on design management. Journal of Product Innovation Management, XXVIII(3), 384-388.

Veryzer, R. W. (1998) Discontinuous innovation and the new product development process. Journal of Product Innovation Management, XV(4), 304-321. 
Von Grogh, G., Ichijo, K., \& Nonaka, I. (2000). Enabling Knowledge Creation. How to Unlock the Mistery of Tacit Knowledge and Release the Power of Innovation. Oxford University Press: New York.

Wang, J., \& Wallendorf, M. (2006). Materialism, status signaling, and product satisfaction. Journal of the Academy of Marketing Science, XXXIV(4), 494-505.

Wernerfelt, B. (1984). A resource-based view of the firm. Strategic Management Journal, V(2), $171-180$.

Wilson, N., Wright, M., \& Scholes, L. (2013). Family business survival and the role of boards. Entrepreneurship Theory and Practice, XXXVII(6), 1369-1389.

Winter, S. G. (2003). Understanding dynamic capabilities. Strategic Management Journal, XXIV(10), 991-995.

Wright, M., Chrisman, J. J., Chua, J. H., \& Steier, L. P. (2014). Family enterprise and context. Entrepreneurship Theory and Practice, XXXVIII(6), 1247-1260.

Zack, M. H. (1999). Managing codified knowledge. Sloan Management Review, XL(4), 45-58.

Zahra, S. A., \& George, G. (2002). Absorptive capacity: A review, reconceptualization, and extension. Academy of Management Review, XXVII(2), 185-203.

Zahra, S. A. \& Wright, M. (2011). Entrepreneurship's next act. Academy of Management Perspectives, $X X V(4), 67-83$

Zellweger, T. M., Nason, R. S., \& Nordqvist, M. (2012). From longevity of firms to transgenerational entrepreneurship of families introducing family entrepreneurial orientation. Family Business Review, XXV(2): 136-155. 
Table 1. Illustrative cases of Family Firms that Innovate Through Tradition

\begin{tabular}{|c|c|c|c|c|c|c|}
\hline & Aboca & Apreamare & Beretta & Lavazza & Sangalli & Vibram \\
\hline Founded & 1978 & 1849 & 1526 & 1895 & 1972 & 1937 \\
\hline Founder & Valentino Mercati & Giovanni Aprea & Bartolomeo Beretta & Luigi Lavazza & Maria Sangalli & Vitale Bramani \\
\hline Annual turnover & $€ 108$ million & $€ 20$ million & $€ 480$ million & $€ 1.34$ billion & $€ 2$ million & $€ 200$ million \\
\hline Employees & 740 & 110 & 850 & 1,590 & 10 & 240 \\
\hline $\begin{array}{l}\text { Generation of } \\
\text { family control }\end{array}$ & Second & Fifth & Fifteenth & Fifth & Second & Second \\
\hline Sector & $\begin{array}{l}\text { Natural healthcare } \\
\text { and beauty products }\end{array}$ & Boat builder & Firearms & Coffee products & Haute couture & $\begin{array}{l}\text { High performance } \\
\text { rubber soles for } \\
\text { footwear }\end{array}$ \\
\hline $\begin{array}{l}\text { Sources of past } \\
\text { knowledge }\end{array}$ & $\begin{array}{l}\text { Territory tradition: } \\
\text { Ancient officinal } \\
\text { herbs from the } \\
\text { territory }\end{array}$ & $\begin{array}{l}\text { Territory tradition: } \\
\text { Manufacturing } \\
\text { skills and product } \\
\text { signs characterizing } \\
\text { old craftsmanship } \\
\text { in Sorrento. }\end{array}$ & $\begin{array}{l}\text { Firm tradition: } \\
\text { Craftsmanship skills } \\
\text { handed down from } \\
\text { generation to } \\
\text { generation in the } \\
\text { firm. }\end{array}$ & $\begin{array}{l}\text { Firm tradition: } \\
\text { Traditional coffee } \\
\text { blending techniques } \\
\text { in the firm. }\end{array}$ & $\begin{array}{l}\text { Territory tradition: } \\
\text { Traditional high } \\
\text { fashion heritage } \\
\text { characterizing the } \\
\text { area of Milan. }\end{array}$ & $\begin{array}{l}\text { Firm tradition: } \\
\text { Historical values and } \\
\text { passion for hiking } \\
\text { and nature in the } \\
\text { firm. }\end{array}$ \\
\hline $\begin{array}{l}\text { Product } \\
\text { innovation }\end{array}$ & $\begin{array}{l}\text { New functions: } \\
\text { Properties of ancient } \\
\text { and mostly forgotten } \\
\text { herbs combined with } \\
\text { up-to-date } \\
\text { technologies enable } \\
\text { effective drugs } \\
\text { without the side } \\
\text { effects. }\end{array}$ & $\begin{array}{l}\text { New meanings: } \\
\text { Luxury yachts } \\
\text { based on the } \\
\text { traditional "gozzo } \\
\text { sorrentino" design } \\
\text { of fishing boats in } \\
\text { the area of } \\
\text { Sorrento. }\end{array}$ & $\begin{array}{l}\text { New functions: } \\
\text { Traditional materials } \\
\text { combined with } \\
\text { innovative polymers } \\
\text { and revolutionary } \\
\text { technologies provide } \\
\text { firearms with } \\
\text { radically superior } \\
\text { performance. }\end{array}$ & $\begin{array}{l}\text { New functions: } \\
\text { Traditional coffee } \\
\text { blending processes } \\
\text { combined with } \\
\text { innovative } \\
\text { technologies enable } \\
\text { a capsule-based } \\
\text { espresso system to } \\
\text { work in extreme } \\
\text { conditions. }\end{array}$ & $\begin{array}{l}\text { New meanings: } \\
\text { Traditional } \\
\text { Milanese sewing } \\
\text { techniques } \\
\text { combined with } \\
\text { innovative } \\
\text { materials change } \\
\text { the meaning of } \\
\text { high fashion } \\
\text { clothing. }\end{array}$ & $\begin{array}{l}\text { New meanings: } \\
\text { The meaning of sport } \\
\text { shoes is changed by a } \\
\text { line of minimalist } \\
\text { shoes that mimics the } \\
\text { look and mechanics } \\
\text { of being barefoot. }\end{array}$ \\
\hline $\begin{array}{l}\text { Examples of new } \\
\text { products }\end{array}$ & $\begin{array}{l}\text { GrinTuss, Melilax, } \\
\text { Sollievo Bio 90, } \\
\text { Adiprox and } \\
\text { NeoBianacid }\end{array}$ & $\begin{array}{l}\text { Apreamare } 40 \\
\text { Dongiovanni }\end{array}$ & A400 Xcel & $\begin{array}{l}\text { A Modo Mio, } \\
\text { ISSpresso }\end{array}$ & Light My Night & $\begin{array}{l}\text { FiveFingers, Speed } \\
\text { Ascent, Rollingait } \\
\text { System }\end{array}$ \\
\hline $\begin{array}{l}\text { Awards and } \\
\text { recognitions }\end{array}$ & $\begin{array}{l}\text { "Tuscany Award" for } \\
\text { excellence and } \\
\text { innovativeness. }\end{array}$ & $\begin{array}{l}\text { Included in the } \\
\text { final list of the } \\
\text { "Motor Boat of the } \\
\text { Year" award. }\end{array}$ & $\begin{array}{l}\text { "Shotgun of the } \\
\text { Year" award from } \\
\text { the American Hunter } \\
\text { Association. }\end{array}$ & $\begin{array}{l}\text { "Coffee Innovation } \\
\text { Award" }\end{array}$ & $\begin{array}{l}\text { "Creativity } \\
\text { Award" by the } \\
\text { Italian Chamber of } \\
\text { Fashion. }\end{array}$ & $\begin{array}{l}\text { "OutDoor Industry } \\
\text { Award" }\end{array}$ \\
\hline
\end{tabular}


Table 2. Typology of ITT Strategies by Source of Past Knowledge and Type of Product Innovation

\begin{tabular}{|c|c|c|}
\hline \multirow{2}{*}{$\begin{array}{l}\text { Source of Past } \\
\text { Knowledge }\end{array}$} & \multicolumn{2}{|c|}{ Type of Product Innovation } \\
\hline & Innovating Product Functionalities & Innovating Product Meanings \\
\hline Firm Tradition & $\begin{array}{l}\text { Interiorizing knowledge from the firm's } \\
\text { past (raw materials and manufacturing } \\
\text { processes) and reinterpreting these to } \\
\text { enable new product functionalities. } \\
\text { Case examples: Beretta, Lavazza. }\end{array}$ & $\begin{array}{l}\text { Interiorizing knowledge from the firm's past } \\
\text { (basic assumptions and beliefs) and } \\
\text { reinterpreting these to enable new product } \\
\text { meanings. } \\
\text { Case example: Vibram. }\end{array}$ \\
\hline $\begin{array}{l}\text { Territorial } \\
\text { Tradition }\end{array}$ & $\begin{array}{l}\text { Interiorizing knowledge from the territory's } \\
\text { past (raw materials and manufacturing } \\
\text { processes) and reinterpreting these to } \\
\text { enable new product functionalities. } \\
\text { Case example: Aboca. }\end{array}$ & $\begin{array}{l}\text { Interiorizing knowledge from the territory's } \\
\text { past (product signs and manufacturing } \\
\text { processes) and reinterpreting these to enable } \\
\text { new product meanings. } \\
\text { Case examples: Apreamare, Sangalli. }\end{array}$ \\
\hline
\end{tabular}


Table 3. Directions for Future Research on Innovation Through Tradition

\begin{tabular}{|c|c|c|}
\hline $\begin{array}{l}\text { Building blocks of } \\
\text { the ITT Model }\end{array}$ & Research gaps & Research Questions \\
\hline \multirow[t]{3}{*}{$\begin{array}{l}\text { Sources of Past } \\
\text { Knowledge }\end{array}$} & $\begin{array}{l}\text { RG \#1: Addressing varying } \\
\text { sources of past knowledge, } \\
\text { origins and evolution of } \\
\text { tradition, including the role } \\
\text { of family and non-family } \\
\text { firms. }\end{array}$ & $\begin{array}{l}\text { RQ \#1A: Do other sources of past knowledge exist in addition to firm tradition and territory tradition? } \\
\text { RQ \#1B: How does tradition emerge? How do the experiences, heuristics and routines embedded in an } \\
\text { industry contribute to create and change firm and territory traditions? How do national, regional and } \\
\text { organizational culture influence the existence and type of tradition? Do family and non-family firms } \\
\text { contribute differently to these processes? } \\
\text { RQ \#1C: Do firms actively take part in the creation and change of tradition? How do they do so? }\end{array}$ \\
\hline & $\begin{array}{l}\text { RG \#2: Clarifying } \\
\text { relationships between firm } \\
\text { tradition and territory } \\
\text { tradition, including the role } \\
\text { of family owners and } \\
\text { managers. }\end{array}$ & $\begin{array}{l}\text { RQ \#2A: Are there mutual relationships between firm tradition and territory tradition? Does the } \\
\text { presence of a controlling family facilitate these links? } \\
\text { RQ \#2B: How do firms navigate different sources of past knowledge? Are firm tradition and territory } \\
\text { tradition substitutes or complementary? When and under what circumstances do firms rely more on } \\
\text { firm tradition or territory tradition? }\end{array}$ \\
\hline & $\begin{array}{l}\text { RG \#3: Identifying optimum } \\
\text { levels of past knowledge } \\
\text { search and its determinants, } \\
\text { including differences } \\
\text { between family and non- } \\
\text { family firms. }\end{array}$ & $\begin{array}{l}\text { RQ \#3: To what extent should firms search knowledge in the past? Is there a too-much-of-a-good-thing } \\
\text { effect that reduces the marginal benefits from using sources of past knowledge and/or triggers negative } \\
\text { consequences for innovation? To what extent this potential optimum level differs between family and } \\
\text { non-family firms? }\end{array}$ \\
\hline \multirow[t]{2}{*}{$\begin{array}{l}\text { Forms of Past } \\
\text { Knowledge }\end{array}$} & $\begin{array}{l}\text { RG \#4: Addressing the } \\
\text { variety of forms of past } \\
\text { knowledge and the flow of } \\
\text { such knowledge, especially } \\
\text { in multi-generational family } \\
\text { firms. }\end{array}$ & $\begin{array}{l}\text { RQ \#4A: How do firms store and retrieve past knowledge? How does the in-flow of past knowledge } \\
\text { relate to existing knowledge stock in the firm? At what levels (e.g., individual, group, inter-group, } \\
\text { organization) do different forms of past knowledge exist? How are different forms of past knowledge } \\
\text { translated and used across individual, group, inter-group, and organization levels? How is past } \\
\text { knowledge handed down in multi-generational family firms? } \\
\text { RQ \#4B: What is the relationship between different configurations of codified and tacit knowledge and } \\
\text { product innovation? Are there differences between family and non-family firms in how knowledge is } \\
\text { stored and retrieved? }\end{array}$ \\
\hline & $\begin{array}{l}\text { RG \#5: Exploring the } \\
\text { intellectual property issues }\end{array}$ & $\begin{array}{l}\text { RQ \#5A: How do firms protect their intellectual property? Are there differences between family and } \\
\text { non-family firms? }\end{array}$ \\
\hline
\end{tabular}




\begin{tabular}{|c|c|c|}
\hline & $\begin{array}{l}\text { associated with past } \\
\text { knowledge, and how these } \\
\text { issues are addressed } \\
\text { differently by family and } \\
\text { non-family firms. }\end{array}$ & $\begin{array}{l}\text { RQ \#5B: What are the intellectual property protection advantages and disadvantages associated with } \\
\text { different forms of past knowledge? What advantages and disadvantages do family firms have in } \\
\text { addressing these issues, compared to non-family firms? }\end{array}$ \\
\hline \multirow[t]{2}{*}{$\begin{array}{l}\text { Types of Product } \\
\text { Innovation }\end{array}$} & $\begin{array}{l}\text { RG \#6: Investigating the } \\
\text { (non-linear) effects of past } \\
\text { knowledge on innovation } \\
\text { performance and how such } \\
\text { effect differ in family and } \\
\text { non-family firms. }\end{array}$ & $\begin{array}{l}\text { RQ \#6A: How does the use of past knowledge affect the introduction of new products and the returns } \\
\text { from innovations? Do family firms have advantages in using past knowledge to innovate? } \\
\text { RQ \#6B: Do innovations of functionality and meaning based on past knowledge have different } \\
\text { implications for innovation performance? In what circumstances are innovations of functionality and } \\
\text { meaning more likely to result in higher/lower innovation performance? How do family firms differ } \\
\text { from their non-family counterparts in developing innovations exploiting past functionalities and } \\
\text { meanings? }\end{array}$ \\
\hline & $\begin{array}{l}\text { RG \#7: Extending the } \\
\text { boundaries of the ITT model } \\
\text { to family and nonfamily } \\
\text { firms in the context of other } \\
\text { types of innovation. }\end{array}$ & $\begin{array}{l}\text { RQ \#7A: Does ITT benefit service, process, organizational, and business model innovation? How do } \\
\text { the challenges of ITT differ across these different forms of innovation? Do family and non-family firms } \\
\text { differ in the way they address these challenges? } \\
\text { RQ \#7B: How do past knowledge and ITT relate to different types of innovation (e.g., } \\
\text { continuous/discontinuous, incremental/radical, supportive/disruptive, flexible/inflexible innovations)? } \\
\text { Do the advantages of family firms in using past knowledge apply differently to different types of } \\
\text { innovations? }\end{array}$ \\
\hline \multirow[t]{2}{*}{ ITT Capabilities } & $\begin{array}{l}\text { RG \#8: Investigating the } \\
\text { micro-foundations of ITT } \\
\text { capabilities in family and } \\
\text { non-family firms. }\end{array}$ & $\begin{array}{l}\text { RQ \#8A: How are the interiorization and reinterpretation capabilities related to individual cognition and } \\
\text { to the interaction of individuals within organizations? Are these capabilities different in family and } \\
\text { non-family firms? } \\
\text { RQ \#8B: How do communities of practice and technological gatekeepers enable interiorizing and } \\
\text { reinterpreting past knowledge in the organization? How do family an non-family firms contribute to } \\
\text { building such communities of practice? } \\
\text { RQ \#8C: How do organizational routines, histories, stories, documentation, and procedures, concur in } \\
\text { creating shared understandings of the knowledge at the organization level and interiorizing and } \\
\text { reinterpreting past knowledge? Under which conditions do family firms have advantages in building } \\
\text { ITT capabilities? }\end{array}$ \\
\hline & $\begin{array}{l}\text { RG \#9: Clarifying } \\
\text { relationships between }\end{array}$ & $\begin{array}{l}\text { RQ \#9A: How does the interiorization capability relate sources of past knowledge (firm and territory } \\
\text { tradition) to forms of past knowledge (codified and tacit knowledge)? Do family firms always have }\end{array}$ \\
\hline
\end{tabular}




\begin{tabular}{|c|c|c|}
\hline & $\begin{array}{l}\text { sources of past knowledge, } \\
\text { forms of past knowledge } \\
\text { and product innovation, in } \\
\text { family and non-family } \\
\text { firms. }\end{array}$ & $\begin{array}{l}\text { advantages in developing such links? } \\
\text { RQ \#9B: How does the reinterpretation capability relate forms of past knowledge (codified and tacit } \\
\text { knowledge) to types of product innovation (new functionalities and new meanings)? Do family firms } \\
\text { always have advantages in developing such links? }\end{array}$ \\
\hline & $\begin{array}{l}\text { RG \#10: Exploring the } \\
\text { drivers of heterogeneity and } \\
\text { variation of ITT capabilities } \\
\text { between family and non- } \\
\text { family firms and among } \\
\text { different types of family } \\
\text { firms. }\end{array}$ & $\begin{array}{l}\text { RQ \#10A: What are the managerial, organizational and inter-organizational drivers of heterogeneity in } \\
\text { the interiorization and reinterpretation capabilities? } \\
\text { RQ \#10B: Do family firms have superior ITT capabilities than non-family firms? How does the family } \\
\text { willingness (e.g., values, goals, objectives) and ability (e.g., power concentration, participative decision } \\
\text { making) relate to differences in ITT between family and non-family firms and heterogeneity among } \\
\text { family firms? } \\
\text { RQ \#10C: How do ITT capabilities evolve over time? How do situational and temporal factors such as } \\
\text { succession and generation influence ITT capabilities over time? }\end{array}$ \\
\hline Contextual Factors & $\begin{array}{l}\text { RG \#11: Incorporating the } \\
\text { effects of exo-context and } \\
\text { chrono-context and } \\
\text { empirically validating and } \\
\text { generalizing the ITT model. }\end{array}$ & $\begin{array}{l}\text { RQ \#11A: Is ITT more viable in certain industries, and why? } \\
\text { RQ \#11B: How does the economic, social, political, legal, cultural, spatial and technological } \\
\text { environment influence the viability of ITT? } \\
\text { RQ \#11C: How does the chrono-context (e.g., global and national crises) influence the viability of ITT? }\end{array}$ \\
\hline & $\begin{array}{l}\text { RG \#12: Investigating how } \\
\text { ITT is applied outside the } \\
\text { family business context. }\end{array}$ & $\begin{array}{l}\text { RQ\#12A: Which managerial practices and approaches are applied by non-family businesses to employ } \\
\text { the ITT strategy? } \\
\text { RQ \#12B: How does the application of ITT differs in forms and significance among different types of } \\
\text { non-family firms (e.g., widely-held corporations, cooperative ventures, joint ventures, venture capital- } \\
\text { backed firms, state-owned firms)? }\end{array}$ \\
\hline
\end{tabular}


Figure 1. A Model of Innovation Through Tradition

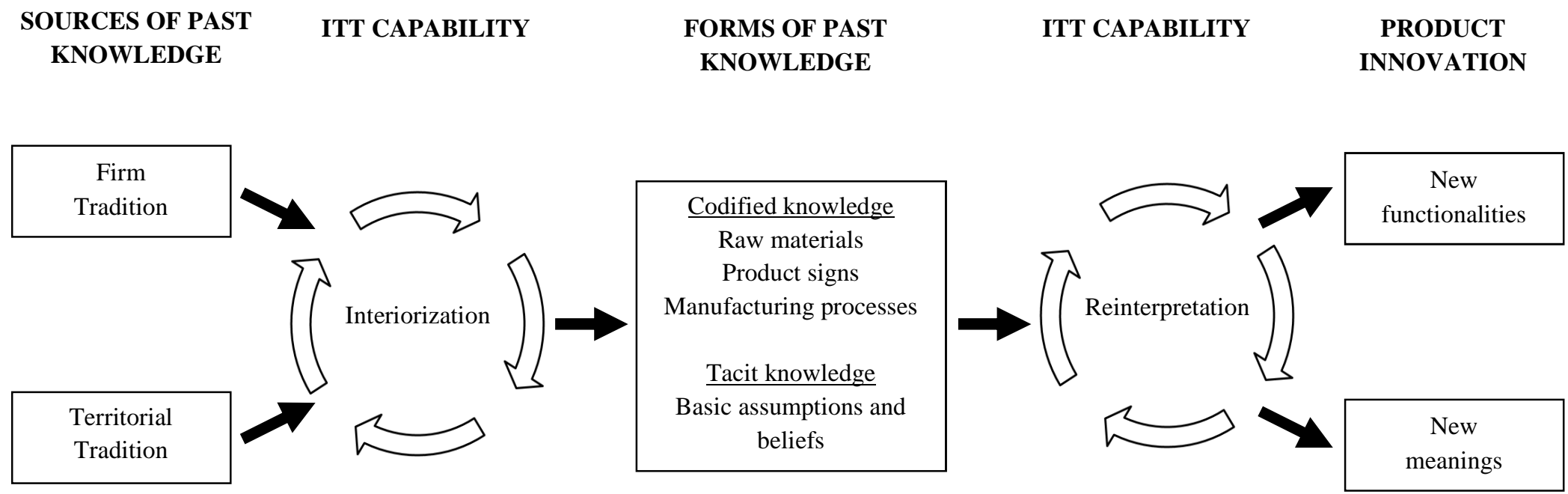




\section{AUTHROS BIOs}

Alfredo De Massis (a.demassis@lancaster.ac.uk) is Professor of Entrepreneurship \& Family Business at Lancaster University Management School and Director of the School's Centre for Family Business. He serves on the Editorial Boards of ET\&P, FBR, SEJ, JFBS. In September 2015, Family Capital ranked him among the world's top 25 star professors for family business.

Josip Kotlar (j.kotlar@lancaster.ac.uk) is Assistant Professor at the Department of Entrepreneurship, Strategy and Innovation of the Lancaster University Management School, and member of the School's Centre for Family Business. His research is at the intersection of strategy, entrepreneurship and innovation, and his work focuses primarily on family businesses.

Federico Frattini (Federico.frattini@polimi.it) is Associate Professor at the School of Management of Politecnico di Milano, where he is also Director of the MBA and Executive MBA programs. In 2013, he was nominated among the Top 50 Authors of Technology and Innovation Management worldwide by the International Association for Management of Technology.

Antonio Messeni Petruzzelli (antonio.messenipetruzzelli@poliba.it) is Assistant Professor and co-founder of the Innovation-Management Group at the Politecnico di Bari. His studies on the value of temporal search have recently been awarded the Nokia Siemens Network Award in Technology Management for Innovation into the Future.

Mike Wright (mike.wright@imperial.ac.uk) is Professor of Entrepreneurship at Imperial College Business School, visiting Professor at the University of Ghent and Director of the Centre for Management Buy-out Research. He chaired the Academy of Management Entrepreneurship Division and was recently ranked \#1 worldwide for publications in academic entrepreneurship and in entrepreneurship. 